\title{
On the influence of the board's financial education on voluntary disclosure: Evidence from Saudi Arabia
}

\author{
Ibrahim M. Sweiti* \\ Accounting Department, College of Business and Economics (CBE), Qassim University, Buraydah, Saudi Arabia
}

\section{A RT ICLE INFO}

\section{Article history:}

Received 15 December 2016

Received in revised form

16 February 2017

Accepted 20 February 2017

\section{Keywords:}

Voluntary disclosure

Corporate governance

Board financial education

Agency theory

\section{Introduction}

The main objective of this research is to answer an important question: how the board of directors' financial education affects the voluntary disclosure? Most of the previous study did not answer this question. In this paper, we try to state an answer to this question by investigating and inquiring about the financial background of the board of directors on voluntary disclosure. Previous works, consider the board of directors as a central component of corporate governance mechanisms, and they try to prove that there is an association between board of directors and the voluntary disclosure, according to the best of your knowledge, the financial education of the board of directors is not taken as a sign for strength and weakness' of corporate governance. In this study we will try to take the financial education of the board of directors and see how this might be affecting the voluntary disclosure.

Voluntary disclosure, for some companies, may negatively influence competitive advantages, the debates behind that, inclosing more information to the public, will let others come to know what you are going to do, and might use this information against your strategic plan, and may it cost you a lot by reducing your profit (James, 2014). However, there is a wave research paper that argues that voluntary disclosure can be considered as a tool that we may use for protecting the owner's equity, and reduce the

\footnotetext{
* Corresponding Author.

Email Address: im.alswaiti@qu.edu.sa

https://doi.org/10.21833/ijaas.2017.02.021

2313-626X/C 2017 The Authors. Published by IASE.

This is an open access article under the CC BY-NC-ND license

(http://creativecommons.org/licenses/by-nc-nd/4.0/)
}

agency costs by decreasing conflict of interest between managers (agent) and owner's equity (shareholders) (Wang et al., 2008; Alturki, 2015).

The originality of this paper, that it is the first paper that discusses the effect of the board financial education in Saudi Arabia and its effect on the voluntary disclosure. This research is different from other researches which have been done in Saudi Arabia, because it deeply investigates the financial education of the board of directors, and how this education might influence the voluntary disclosure. A key feature in previous studies, that there is a relationship between strong corporate governance and voluntary disclosure. This study will add to the literature of corporate governance a hint that the education of board of directors has an important role of voluntary disclosure. We want to achieve an objective by examining if the financial educations of the board of directors have any influence in voluntary disclosure. Few research have been discussed this issue in developing countries (Gîrbină et al., 2012).

This paper is divided into five additional sections. The second section reviews the appropriate literature and develops our hypothesis. The third section deals with our methodology. Section four includes data description. While, section five reports and discusses our empirical findings. Finally, section six concludes.

\section{Literature review and hypotheses development}

The corporate governance story was spawned by Berle and Means (1932) after the financial crisis in the US. Jensen and Meckling (1976) gave definition 
for agency theory which arrange the relation between owners' equity of the company and the professional management, the agency theory arises as a result of separating the ownership from their management of business, the professional management acts as an agent on behave of the owners' interest ,"a contract under which one or more persons (the principal) engage another person (the agent) to perform some service on their behalf which involves delegating some decision making authority to the agent" (Jensen and Meckling, 1976).

Alturki (2014) pointed out to the agency cost, which it incurred due to conflicts between management (agent) and shareholders (owners). The manager is supposed to provide more information in order to reduce the agency cost. This study wants to concentrate on the voluntary information disclosed by the management in the annual report, as it is known the annual report content mandatory information which is addressed the external parties as well as internal parties, for mandatory information the management must disclose information to the users, in order to inform interested parties about it is acting, voluntary disclosure is more information provided by the agent to the stakeholders specially investors, in order to solve any asymmetry information problem.

\subsection{The board of financial education}

The board of directors is the number of shareholders who is elected by shareholders in general meeting of the owners of the company, in the absence of the shareholders from managing their wealth, the member of the board of directors supposed to act and represent the shareholders will. They are keeping eyes on the management of the company, so they represent the link between shareholders and professional management of the company. The board of directors plays a vital role in the promoting and controlling the management of the company, they watched that the resources of company are utilized effectively and efficiency of the management for the benefit of the shareholders (Clark and Knight, 2008).

Board of directors' qualification plays an important role in controlling and monitoring the management of business, so lack of board of directors' education causes a major shortage in controlling and governance of the business. The education of the board of directors increases the effectiveness and efficiency of the corporate governance of the company, and improves the decision-making capability (Gîrbină et al., 2012). Members of the board of directors with higher education will give more the company for utilizing their sources. Not all education has the same influence and impact on the company corporate governance, financial education will be better than other education. Haniffa and Cooke (2002) pointed out that there is a positive relation between accounting education of board members education and voluntary disclosure. Haniffa and Cooke (2002) found that there is a positive relationship between general business and accounting education of board directors and disclosure of information that demonstrates accountability and credibility of the top management team

$\mathrm{H}_{1}$ : There is a positive association between the Board of Directors Financial Education and the extent of Voluntary disclosure of information in the annual report.

\subsection{Board size}

The board of directors has crucial function. The agency theory argues that there are conflicts of interest between the management and ownerships. These conflicts almost accrued in all business, the duties of the board are to control and reduce these conflicts (Al-Shammari and Al-Sultan, 2010). There is a debate around the board of directors size; one opinion says that less number size are more efficient for controlling over management, Jensen (1993) and Sweiti and Attayah (2013) pointed that less number of board size is more effective controls, Moreover, a smaller board of directors will be more efficient for monitoring the management, operation and will have a great value for reducing the conflict. In so many literatures, it is believed that the large size number has an influence on monitoring the management and reduce the conflict of interest (Dalton et al., 1998; Chaganti et al., 1985). This argues about the suitable board size is still going on.

$\mathrm{H}_{2}$ : There is a positive association between the board size and the level of voluntary disclosure.

\subsection{Board independence}

Healy and Palepu (2001) argued that the conflict between a management of the company and the shareholders can be solved or minimized, if the board of directors are independent, the reason behind that, because non-executive directors are acting on behalf of the benefit of shareholders. The non-executive directors have enjoyed more freedom for controlling management.

$\mathrm{H}_{3}$ : There is a positive correlation between the board independence and the level of voluntary disclosure.

\subsection{Duality}

When the CEO plays double role as chair of the board in addition to CEOs, in this case we can say that there is a role duality (Haniffa and Cooke, 2002) so many studies supporting the duality and argue that when the CEO play a double role so many obstacles can be reduced, and this situation will be so benefited to firm value (Rechner and Dalton, 1991; Mohamed and Jarboui, 2016). According to Haniffa and Cooke (2002), the separation of the board of directors on the CEO will give more independence to chair board for monitoring and controlling the chief executive. 
$\mathrm{H}_{4}$ : There is a positive association between the duality and the level of voluntary disclosure.

\subsection{Firm size}

Several previous studies point out that there is a positive relationship between voluntary disclosure and firm size (Chow and Wong-Boren, 1987; Belkaoui-Riahi, 2001; Haniffa and Cooke, 2002; Barako et al., 2006; Alturki, 2015). Jensen and Meckling (1976) pointed out that the large firm size has a great agency cost than the small firm size, the management of the large firm size disclosed more information in order to reduce the conflicts interest between management and shareholders.

$\mathrm{H}_{5}$ : There is a positive association between the firm size and the level of voluntary disclosure.

\section{Variables measures and models}

Voluntary disclosure is considered as a dependent variable which is followed by so many similar previous researches (Hossain et al. 1994; Meek et al., 1995; Soh, 1996; Haniffa and Cooke, 2002). Disclosure index based on annual report analysis for each selected sample, thoroughly reading of an annual report in order to extract the criteria's related to four general classifications of voluntary disclosure, which are named as, strategic information, non-financial information, financial information and Social and board disclosure. The researcher developed the checklist in order to be suitable for the present research depend on previous study conducted by Barako et al. (2006) and Meek et al. (1995). The scoring is calculated by giving one if disclosure is existed and zero if it is not, and not applicable if item of checklist items is irrelevant. No fines or penalty is imposed on irrelevant items. Two important things should be taken into account while calculating the voluntary disclosure; weighted and unweight of checklist items. And both things were used in literature studies. The weighted mean some items in check listed on voluntary disclosure should be given more weight than other items. But, the problem is while weighted items, biased may be inter fair. Hence weighted items in the checklist are subject to several crisis. Due to this reason, in the current study, we adopted unweight disclosure index, which means that all disclosure index items will carry the same weight (Al-Janadi et al, 2012):

$I_{j}=\frac{\sum_{t=1}^{n j} X_{i j}}{n_{j}}$

where:

$I_{j}$ : The index of voluntary disclosure

$n_{j}$ : number if items expected for $j^{\text {th }}$ firm, $n_{j} \leq 79$

$X_{i j:} 1$ if $i^{\text {thitem }}$ for $j^{\text {th }}$ firm is disclosed, otherwise 0

$$
\begin{gathered}
V D_{i t}=\beta_{0}+\beta_{1} B F E_{i t}+\beta_{2} B S_{i t}+\beta_{3} B I_{i t}+\beta_{4} B D_{i t}+\beta_{5} F S_{i t} \\
\quad+\varepsilon_{i t} \\
V D_{i t}=\beta_{0}++\beta_{1} B S_{i t}+\beta_{2} B I_{i t}+\beta_{3} B D_{i t}+\beta_{4} F S_{i t}+\varepsilon_{i t}
\end{gathered}
$$

where, $V D$ is voluntary disclosure. It is measured using a dummy variable. It is equal to (1) if a company discloses an item and (0) if it does not.

For each firm, a disclosure index was computed as the ratio of the actual score given to the firm divided by the maximum score. BFE: Board Financial education. It is also a dummy variable. It will take 1 if the company, Chairman of Board of Directors has a financial education; 0 if otherwise. BS: Board size and it is measured directly by the number of the member of the board of directors. BI: Board independence. It is the percentage of board independent directors to total Directors. BD: Board duality. It is a dummy variable that will take 1 if the company has role duality; 0 if otherwise FS: Firm size. We use the standard way to measure this variable. We take the $\mathrm{LN}$ of the book value of total Assets for each company. We use the annual reports to extract information about these variables.

\section{Data}

The current study is labeled as an experimental study. This study primarily uses the secondary data, which collected from the websites of listed Saudi companies, or published, by the Saudi exchange market. The covered study period used five years, started from the year 2011 up to 2015, this period considered quite enough to fulfill this study objective. Moreover the previous studies regarding the research have been taken into consideration. Mainly the published annual report for public listed Saudis' companies were used, the annual reports provided both information; financial and nonfinancial, in this study both are used, especially while calculating the voluntary disclosure, the checklist was used to find out the score of voluntary disclosure. The voluntary disclosure is calculated by using almost the same check listed used by Donnelly and Mulcahy (2008). The population of this study is all listed in public Saudi companies, at the period from 2011 to 2015 and, have a published annual report; the number of listed companies in the year 2011 is equal to one hundred fifty companies (150). This study uses a sample consists of 60 companies from different sectors of business. In general the researcher reclassified the listed companies into three sectors, which are, manufacturing sector, services sector, and merchandising sector.

In order to give us a detailed idea around our sample construction, composition and description we can refers to Tables 1 to 3 . In fact, Table 1 presents the sample selected from the Saudi listed companies. The total companies' population is $\mathbf{1 5 0}$ and the sample contents 60 companies out of 150 .

The correlation between variables is summarized in Table 2; it appears that the correlation between variables did not have a strong correlation, which means that we can run the analysis without any problem.

Table 3 shows the descriptive statistics which shows that the maximum mean point for FS(13.24) and the minimum for $\mathrm{BFE}$ and $\mathrm{BD}$ which is equal to 
zero. VD mean for samples is (0.32), the maximum mean for $\mathrm{VD}$ is 0.44 and the minimum is 0,21 which is considered quite low. For BFE and BD we used dummy variable (0),(1) so normally maximum will be (1) and the minimum is equal (0) . For BS the minimum is (4) and maximum is( 12) with the mean equal to (8.55). BI has the maximum mean (1) 1 nd the minimum $(0.16)$ with the mean equal $(0.49) . F S$ has the maximum (13.24) and minimum (4.70) with the mean equal to (7.84).

\section{Results}

Table 4 shows the estimation results of our first model. Using an OLS regression with a fixed effect panel, our results report that the proposed variables are of interest and can explain the voluntary disclosure. In fact, the adjusted R-squared $=0.50$ and this means that our variables highly contribute to the explanation of the studied phenomenon.

The most important finding in this study is that the board financial education has a positive effect on the firm's voluntary disclosure. In fact, the coefficient $\left.\llbracket(\beta)_{-} 1=0.08\right)$ and it is significant at the first percent level $(\mathrm{T}$-statistic $=116$; $\mathrm{p}$-value $=0.000)$. As it is predicted, the positive effect of the board financial education has a positive effect since it can stimulate the decision to voluntary disclose information about firms strategic information, non-financial information, financial information and Social and board disclosure. This relationship can be explained by the fact that when the chairman of the board has a financial education, it is implicitly supposed that it will be aware about the positive effect of the voluntary disclosure decision. In fact, if the chairman of the board is an expert in the domain of accounting and finance, he/she will be able to trace the effect of the voluntary disclosure of firm value.

The effect of corporate governance mechanisms on the voluntary disclosure is also evoked in this study. A surprising finding is that the effect of board characteristics seems to be in contradiction with our prediction. In fact, the board size seems to have poor and positive effects on voluntary disclosure $\left(\beta_{2}=\right.$ 0.006). It is also significant at the first percent level (T-statistic $=27.18 ; \mathrm{p}$-value $=0.000)$. Our finding corroborates previous works which report that the board size has a positive effect on firm strategy and decisions. Big boards may be more efficient in decision making because if the number of experts on the board increases, it will be more efficient and so it can push firm managers to adopt a voluntary disclosure strategy.

The board independence seems to have a negative and significant effect on voluntary disclosure $\left(\beta_{3}=-0.081\right)$ and (T-statistic $=39.40 ; \mathrm{p}$ value $=0.000)$. This means that the existence of independent board members decreases the probability that a firm adopts voluntary disclosure. This result is surprising, but it can be explained as follows; if the board independence is low, this means that the board members are also engaged in firm management and they act as managers. This can push them to adopt a voluntary disclosure strategy to show that they work in the profit of the firm and the shareholders. According to the signaling theory (Ross, 1977), they will use the voluntary disclosure to pass a positive signal to the market and potential investors around the quality of their management practice.

The board duality has also a positive and significant effect on voluntary disclosure $\left(\beta_{4}=\right.$ 0.017) (T-statistic $=24.60 ; \mathrm{p}$-value $=0.000)$. Here also we can refer to the signaling theory to explain this positive effect of the board duality. If the CEO is also the chairman of the board, the probability to opt for a voluntary disclosure will increase. Finally, we control for the firm size and we find that large firms do not probably adopt a voluntary disclosure strategy. This is may be due to the specificity of their activity. This relationship is poor, but significant at the first percent level $\left(\beta_{5}=-0.003\right.$ T-statistic $=$ 20.83; p-value $=0.000$ ).

We re-estimate our model, but we exclude the board financial education in a second step. This methodological step is very interesting since we aim to show the importance of including the financial or accounting education of the chairman of the board of directors. Using, an OLS regression and a fixed panel effect, we find the same results that we obtain using model 1. However, the adjusted R-squared highly decreases. It goes from 0.506 to 0.129 . This means that the board financial and accounting education is very interesting when explaining the voluntary disclosure in the Kingdom of Saudi Arabia.

Table 1: Sample description

\begin{tabular}{|c|c|c|c|c|c|}
\hline & \multicolumn{2}{|c|}{ Sector } & \multicolumn{2}{|c|}{ Number of firms } & Percentage \\
\hline \multirow{2}{*}{\multicolumn{3}{|c|}{$\begin{array}{l}\text { Manufacturing and industry } \\
\text { Services }\end{array}$}} & \multicolumn{2}{|c|}{28} & 0.47 \\
\hline & & & \multirow{2}{*}{\multicolumn{2}{|c|}{17}} & 0.28 \\
\hline \multicolumn{3}{|c|}{ Merchandising } & & & \multirow{2}{*}{$\begin{array}{c}0.25 \\
1\end{array}$} \\
\hline \multicolumn{3}{|c|}{ Total } & \multicolumn{2}{|c|}{60} & \\
\hline \multicolumn{6}{|c|}{ Table 2: Correlation matrix } \\
\hline & VD & BFE & BS & $\mathrm{BI}$ & $\mathrm{BD}$ \\
\hline VD & 1 & & & & \\
\hline BFE & 0.154 & 1 & & & \\
\hline BS & 0.400 & 0.088 & 1 & & \\
\hline BI & -0.128 & 0.014 & -0.136 & 1 & \\
\hline BD & 0.168 & 0.183 & 0.008 & 0.169 & 1 \\
\hline FS & $0 .-057$ & -0.055 & 0.377 & -0.296 & -0.09 \\
\hline
\end{tabular}


Table 3: Full sample: summary of descriptive statistics

\begin{tabular}{|c|c|c|c|c|c|c|}
\hline & Observations & Mean & Median & Standard deviation & minimum & Maximum \\
\hline VD & 300 & 0.32 & 0.32 & 0.06 & 0.21 & 0.44 \\
\hline BFE & 300 & 0.45 & 0 & 0.50 & 0 & 1 \\
\hline BS & 300 & 8.55 & 9 & 1.60 & 4 & 12 \\
\hline $\mathrm{BI}$ & 300 & 0.49 & 0.47 & 0.17 & 0.16 & 1 \\
\hline $\mathrm{BD}$ & 300 & 0.38 & 0 & 0.49 & 0 & 1 \\
\hline FS & 300 & 8.50 & 7.84 & 2.18 & 4.70 & 13.24 \\
\hline
\end{tabular}

Table 4: OLS regression of investment on cash flow and optimism measure

\begin{tabular}{|c|c|c|}
\hline & BFE (Fixed effect) & Without BFE (Fixed effect) \\
\hline Intercept $(\mathrm{C}) \times 100$ & $29.72(121.477)^{* * * *}$ & $31.69(97.755)^{* * *}$ \\
\hline BFE & $0.080(116.095)^{* * *}$ & -------- \\
\hline BS & $0.06(27.183)^{* * *}$ & $0.900(29.810)^{* * * *}$ \\
\hline $\mathrm{BI}$ & $-8.17(-39.403)^{* * *}$ & $-8.33(-30.258)^{* * * *}$ \\
\hline $\mathrm{BD}$ & $1.76(24.605)^{* * *}$ & $3.059(32.510)^{* * *}$ \\
\hline FS & $-0.36(-20.832)^{* * *}$ & $-0.505(-21.960)^{* * *}$ \\
\hline $\begin{array}{c}\text { Adjusted R-squared for } 300 \\
\text { Observations }\end{array}$ & 50.66 & 12.96 \\
\hline
\end{tabular}

\section{Conclusion}

In this paper, we present in essay around the determinants of KSA firms' voluntary disclosure in their annual reports. The originality of this research paper, that it discusses the effect of the board financial education of voluntary disclosure. In fact, we test the effect of the board chairman, financial education on firms' voluntary disclosure and we find that it can be considered as one of the most robust factors that can explain why firm can be engaged in the voluntary disclosure. We empirically demonstrate that the level of voluntary disclosure increase with the board financial education level.

We find also that the corporate governance mechanisms still having a strong explanatory power. Especially, the board independence, the duality and the board size are of interest and can explain the decision to voluntarily disclose. We control for the firm size and we find that this variable can negatively affect the voluntary disclosure phenomenon. So, the firm should pay attention to their board skills and their corporate governance mechanisms in order to adopt optimal decision such as that to disclose more information to stakeholders.

\section{References}

Al-Janadi Y, Rahman RA, and Omar NH (2012). The level of voluntary disclosure practices among public listed companies in Saudi Arabia and the UAE: Using a modified voluntary disclosure index. International Journal of Disclosure and Governance, 9(2): 181-201.

Al-Shammari B and Al-Sultan W (2010). Corporate governance and voluntary disclosure in Kuwait. International Journal of Disclosure and Governance, 7(3): 262-280.

Alturki KH (2014). Corporate governance: Factors influencing voluntary disclosure by publicly traded Saudi Arabian firms. International Journal of Accounting and Financial Management Research (IJAFMR), 4(5): 15-38.

Alturki KH (2015). Voluntary disclosure by Saudi companies. Research Journal of Finance and Accounting, 5(20): 77-94.

Barako DG, Hancock P, and Izan HY (2006). Relationship between corporate governance attributes and voluntary disclosures in annual reports: the Kenyan experience. Financial Reporting, Regulation and Governance, 5(1): 1-26.
Belkaoui-Riahi A (2001). Level of multinationality, growth opportunities, and size as determinants of analyst ratings of corporate disclosures. American Business Review, 19(2): 115120.

Berle A and Means G (1932). The Modern corporation and private property. Macmillan, New York, USA.

Chaganti RS, Mahajan V, and Sharma S (1985). Corporate board size, composition and corporate failures in retailing industry. Journal of Management Studies, 22(4): 400-417.

Chow CW and Wong-Boren A (1987). Voluntary financial disclosure by Mexican corporations. Accounting Review, 62(3): 533-541.

Clark GL and Knight ER (2008). Implications of the UK companies act 2006 for institutional investors and the market for corporate social responsibility. University of Pennsylvania Journal of Business Law, 11(2): 259-296.

Dalton DR, Daily CM, Ellstrand AE, and Johnson JL (1998). Metaanalytic reviews of board composition, leadership structure, and financial performance. Strategic Management Journal, 19(3): 269-290.

Donnelly R and Mulcahy M (2008). Board structure, ownership, and voluntary disclosure in Ireland. Corporate Governance: An International Review, 16(5): 416-429.

Gîrbină MM, Albu CN, and Albu N (2012). Board members' financial education and firms' performance: empirical evidence for Bucharest stock exchange companies. World Academy of Science, Engineering and Technology, International Journal of Social, Behavioral, Educational, Economic, Business and Industrial Engineering, 6(9): 23432347.

Haniffa RM and Cooke TE (2002). Culture, corporate governance and disclosure in Malaysian corporations. Abacus, 38(3): 317 349.

Healy PM and Palepu KG (2001). Information asymmetry, corporate disclosure, and the capital markets: A review of the empirical disclosure literature. Journal of Accounting and Economics, 31(1): 405-440.

Hossain M, Tan ML, and Adams M (1994). Voluntary disclosure in an emerging capital market: Some empirical evidence from companies listed on the KLSE. The International Journal of Accounting, 29(4): 334-351

James SD (2014). The use of voluntary public disclosure and patent strategies to capture value from product innovation. The Journal of Applied Business and Economics, 16(5): 11-26.

Jensen MC (1993). The modern industrial revolution, exit, and the failure of internal control systems. The Journal of Finance, 48(3): 831-880. 
Jensen MC and Meckling WH (1976). Theory of the firm: Managerial behavior, agency costs and ownership structure. Journal of Financial Economics, 3(4): 305-360.

Meek GK, Roberts CB, and Gray SJ (1995). Factors influencing voluntary annual report disclosures by US, UK and continental European multinational corporations. Journal of international business studies, 26(3): 555-572.

Mohamed BE and Jarboui S (2016). Do corporate governance mechanisms affect public transport firm value?. Journal of the Knowledge Economy: 1-13. https://doi.org/10.1007/s13132-0150302-3

Rechner PL and Dalton DR (1991). CEO duality and organization performance: A longitudinal analysis. Strategic Management journal, 12(2):155-160.
Ross SA (1977). The determination of financial structure: The incentive-signalling approach. The Bell Journal of Economics, 8(1): 23-40.

Soh CS (1996). Factors influencing company information disclosure: an empirical study of companies listed on the KLSE. Ph.D. Dissertation, University of Warwick, Coventry, UK.

Sweiti IM and Attayah OF (2013). Critical factors influencing voluntary disclosure: The Palestine exchange "PEX". Global Journal of Management and Business Research, 13(6): 1-9.

Wang K, Sewon O, and Claiborne MC (2008). Determinants and consequences of voluntary disclosure in an emerging market: Evidence from China. Journal of International Accounting, Auditing and Taxation, 17(1): 14-30. 